DOI 10.47315/archives2021.329.138

УДК 314.151.5:341.341-052(=161.2)]«1918/192»:[930.253:004]

\author{
ORCID: https://orcid.org/0000-0003-1353-3001

\section{ЦИФРОВІ АРХІВНІ РЕСУРСИ ЯК ДЖЕРЕЛО ВИВЧЕННЯ ПРОЦЕСУ РЕПАТРІАЦЇ̈ ПОЛОНЕНИХ УКРАЇНЩІВ ПІСЛЯ ПЕРШОЇ СВІТОВОЇ ВІЙНИ}

Мілана Срібняк

магістерка історії, аспірантка,

ДУ «Інститут всесвітньої історії НАН України»

\begin{abstract}
Анотація. Мета статті полягає у визначенні й систематизації цифрових архівних ресурсів із теми репатріації полонених українців після Першої світової війни; аналізі контенту українських і зарубіжних баз даних та оцифрованих архівних колекцій, в яких представлені документи з цієї дослідницької проблеми. Методологія дослідження включає принципи історизму, всебічності, наступності; у дослідженні використані методи компаративного аналізу і синтезу, системний і міждисциплінарний підходи. Вивчення архівних ресурсів відбувалося крізь призму підходів цифрової гуманітаристики. Наукова новизна. Здійснено характеристику комплексу оцифрованих документів з українських і зарубіжних архівів, що відображають процес репатріації полонених після Першої світової війни. Особливу увагу звернено на розширення доступу науковців до оцифрованих архівних ресурсів. Висвітлено значення цифрової гуманітаристики та ії вплив на сучасні дослідницькі практики. Простежено особливості репрезентації фондів і колекцій на сайтах українських і зарубіжних архівів, бібліотек та інших інституцій. Висновки та перспективи подальших досліджень. Встановлено, що питання репатріації полонених після Першої світової війни, у т. ч. українців, поступово стає все більш репрезентованим у цифровому просторі. Визначено роль і місце цифрових архівних ресурсів у дослідженні процесу репатріації, систематизовано основні групи джерел, що представлені у базах даних та виставкових проєктах українських і зарубіжних архівів, зокрема Центрального державного архіву вищих органів влади та управління України, Центрального державного архіву зарубіжної україніки, Федерального архіву Німеччини, порталу «Europeana» тощо. Підкреслено, що перспективним напрямом подальших наукових студій $є$ поглиблене вивчення цифрового контенту зарубіжних архівів і бібліотек із метою виявлення цінних джерел з української історії.
\end{abstract}

Ключові слова: цифрові архівні ресурси; історичні джерела; полонені українці; репатріація; Перша світова війна; інформаційний потенціал; цифрова гуманітаристика. 
В епоху інформаційної революції та все більшого розмаїття електронних ресурсів українські і зарубіжні архівні установи, бібліотеки й окремі електронні проєкти і веб-портали надають користувачам доступ до оцифрованих документів різних історичних періодів. Стратегічна орієнтація архівної спільноти в бік діджиталізації архівної інформаціїтобто, оцифрування наявних в архівних фондах документів на паперових та інших носіях - стає все більш визначальною для проведення досліджень науковцями, особливо гуманітарного профілю.

У світлі зазначених трансформацій важливо виокремити новий науковий напрям - цифрову гуманітаристику («Digital Humanities») міждисциплінарну галузь, яка об’єднує як історію, так і соціологію, економіку, антропологію, археологію з інформаційними технологіями та вивчає широке розмаїття джерел, залишених людством ${ }^{1}$. Нові підходи в аналітичному опрацюванні джерел суттєво впливають на аналіз цифрових ресурсів - як створених в електронній формі, так і оцифрованих традиційних документів.

Нові реалії інформаційного простору й зумовлюють переосмислення теоретичних і практичних аспектів систематизації, зберігання та використання електронних і оцифрованих документів. Подібні зміни впливають передовсім на діяльність традиційних інституцій збереження історичної пам'яті, зокрема архіви й бібліотеки. Архіви споконвічно асоціюються з репозиторіями оригінальних, неопублікованих документів, а принцип провенієнції (походження) є ключовим підгрунтям для формування архівних фондів. В інформаційному просторі цей розподіл стає все більш умовним, адже електронні копії документів відкриті для широкого доступу, а цифрова репрезентація зібрань архівів і бібліотек як інститутів пам'яті відбувається не лише в локальних базах даних, але й в національних і міжнародних інтегрованих ресурсах документальної спадщини ${ }^{2}$.

Проблематикою електронного документознавства й архівознавства, археографії, теоретичних і практичних питань оцифрування документів на традиційних носіях інформації, цифрової гуманітаристики займалася низка українських і зарубіжних науковців. Серед українських дослідників варто виокремити праці Г. Боряка, Л. Дубровіної, Ю. Ковтанюка, Т. Смельянової, Л. Левченко, А. Хромова, Я. Калакури, М. Палієнко, Г. Папакіна, В. Кулікова, Т. Білущак ${ }^{3}$; серед закордонних - Т. Кука

1 Gold M. K. Debates in the Digital Humanities. Minnesota, 2012. P. 52.

2 Hedstrom M. Electronic Archives: Integrity and Access in the Network Environment // The American Archivist. 1995. Vol. 58. P. 316.

3 Боряк Г. В. Електронні архівні публікації в Інтернеті: проблеми репрезентації інформаційних ресурсів // Архіви України. 2002. № 4-6(250). С. 141-169; Дубровіна Л. А. Основні положення концепції комп’ютеризації архівної справи // Студії з архів. справи та документознавства. 1998. Т. 3. С. 6-17; Ковтанюк Ю. Витоки електронного документознавства як наукового 
(T. Cook), М. Гедстром (M. Hedstrom), К. Ворвікк (C. Warwick), М. Голда (M. K. Gold) та ін. ${ }^{4}$

Українські та зарубіжні архіви і бібліотеки ефективно переосмислюють усталені підходи до роботи з інформаційними ресурсами відповідно до нових вимог цифрового суспільства. Водночас на процес оцифрування документів впливає низка факторів, серед яких - швидкі зміни носіїв інформації, видатки на придбання високовартісного обладнання й технічного забезпечення, потреба у кваліфікованих IT-спеціалістах. Більше того, нові запити не лише наукової спільноти, але й широкого кола користувачів інформації вносять корективи до критеріїв систематизації оцифрованих архівами ресурсів ${ }^{5}$. Незважаючи на значні видатки на обладнання, проблему захисту авторських прав, діджиталізація документів і доступ користувачів до баз даних зарубіжних архівів характеризується високими темпами розвитку ${ }^{6}$. Сьогодні цифровізація визнана важливим пріоритетом у діяльності Державної архівної служби України і українських архівів. ${ }^{7}$

напряму документознавства // Архіви України. 2011. № 2-3(273). С. 14-36; Калакура Я., Палієнко М. Концептуалізація електронного архівознавства в контексті цифровізації українського суспільства // Архіви України. 2021. № 3(328). С. 36-65; Смельянова T. Аудіовізуальні колекції: оцифрування та доступ (на прикладі Центрального державного кінофотофоноархіву України імені Г. С. Пшеничного) // Вісник Київського національного університету імені Тараса Шевченка. Історія. 2016. Вип. 3. С. 33-35; Левченко Л., Попова Л., Хромов А. Національні архівні інформаційні ресурси: правові засади реформування архівної справи // Вісник Луганського державного університету внутрішніх справ імені Е. О. Дідоренка. 2021. № 93. Т. 1. С. 249-263; Папакін Г. Сучасна українська інтернет-археографія: основні форми та джерела електронних публікацій // Український історичний журнал. 2010. № 5. С. 153-166; Kyліков B. Digital History: становлення, сучасний стан, перспективи // Спеціальні історичні дисципліни. 2013. Ч. 21. С. 27-44; Білущак T. Питання доступу до історико-культурної спадщини України: електронні архіви // Інформація, комунікація та управління знаннями у глобалізованому світі : зб. матер. Другої міжн. наукової конференції (Київ, 16-18 травня 2019 р.). Київ, 2019. С. 20-23 та ін.

Cook T. Electronic Records, Paper Minds: The Revolution in Information Management and Archives in the Post-Custodial and Post-Modernist Era // Archives \& Social Studies: A Journal of Interdisciplinary Research. 2007. Vol. 1. P. 399-443; Hedstrom M. Electronic Archives: Integrity and Access in the Network Environment... P. 312-324; Warwick C., Terras M., Nyhan J. Digital Humanities in Practice. Facet Publishing, 2021. 192 pp.; Gold M. K. Debates in the Digital Humanities. Minnesota, 2012. 516 p.

5 Warwick C., Terras M., Nyhan J. Digital Humanities in Practice... P. 50.

6 Prelinger $R$. Archives and Access in the 21st Century // Cinema Journal. 2007. Vol. 46. № 3. P. 114.

7 Стратегія розвитку архівної справи на період до 2025 року (проєкт) // Архіви України. 2020. № 4(325). С. 15-16. 
Важливе місце у репрезентації архівних ресурсів широкому колу користувачів відіграють архівні портали, сайти, бази даних, сторінки архівів у соціальних мережах. Виставкові онлайн-проєкти архівних, бібліотечних і музейних установ сприяють поширенню інформації про пам'ятки історико-культурної спадщини та їхньої популяризації. Соціальні мережі відіграють важливе значення для швидкого інформування про нові ініціативи установ щодо оцифрування документів, сприяють кращій обізнаності користувачів 3 архівними фондами. Отже, значення діджиталізації колекцій полягає не лише у розширенні вільного доступу користувачів до ресурсів, але й у сприянні їх збереженню, вивченню і використанню джерельного потенціалу.

Інформаційні ресурси, які є результатом оцифрування і публікації архівних документів, можна умовно охарактеризувати як «цифрові архівні ресурси». Запровадження цього терміна зумовлено новим вектором розвитку археографії - науки про пошук, описування і публікацію історичних документів. Як зазначав Г. Папакін, завдяки стрімкому розвитку технологій нове відгалуження цієї науки - електронна археографія - суттєво впливає на явище оцифрування архівних документів, не обмежуючись лише писемними пам'ятками, а й охоплюючи аудіовізуальні ${ }^{8}$. Важливо наголосити, що на противагу електронним документам, які первинно створюються в електронному форматі («born-digital records»), оцифровані пам'ятки («digitised records») i «цифрові архіви» загалом є особливими, відсканованими формами презентації паперових і аудіовізуальних документів ${ }^{9}$.

Технологічний процес оцифрування документів та їхньої трансформації у «цифровий архівний ресурс» забезпечується можливістю подання двовимірного зображення з відтворенням зовнішніх особливостей матеріальної основи документа ${ }^{10}$. Якісний оцифрований документ може стати об'єктом Інтернет-виставок архівів, бібліотек і суміжних проєктів. На кількісні і якісні показники репрезентації історичних джерел у мережі Інтернет впливає спрямування сайтів електронних архівів і бібліотек, профільних установ, закладів вищої освіти тощо ${ }^{11}$.

Поступово все більш репрезентованим в інформаційних ресурсах вебсайтів мережі Інтернет стає питання репатріації полонених після Першої світової війни, зокрема українців. Джерельний комплекс звітів, постанов, рапортів, офіційної кореспонденції й діловодства, колек-

8 Папакін Г. Сучасна українська інтернет-археографія... С. 153.

9 Калакура Я., Палієнко М. Концептуалізація електронного архівознавства... С. 53.

10 Папакін Г. Електронна археографія: новітній напрям старої науки, іiі складові та стан дослідження // Бібліотекознавство. Документознавство. Інформологія. 2012. № 2. С. 28.

11 Папакін Г. Сучасна українська інтернет-археографія... С. 155. 
тивних звернень, телеграм, щоденників, спогадів тощо представлений не лише у фондах низки українських і зарубіжних архівів, зокрема, у Центральному державному архіві вищих органів влади та управління України (ЦДАВО України), Центральному державному архіві зарубіжної україніки (ЦДАЗУ), Федеральному архіві Німеччини (Bundesarchiv), але й у цифрових репозиторіях «Европіани» (Europeana), Британської бібліотеки (The British Library) тощо.

Основний джерельний масив документів із проблем репатріації полонених українців із теренів Німеччини акумульований у фондах ЦДАВО України. Слід відзначити, що електронні виставки архіву мають цінний джерельний потенціал із цієї проблематики. Особливо вагомий пласт оцифрованих документів, дотичних до проблеми звільнення українців із полону, містить ресурс «Українська революція: архівні хроніки» ${ }^{12}$, приурочений до сторіччя українських визвольних змагань 1917-1921 pр. Цей масштабний проєкт був реалізований упродовж 2017-2021 рр. шляхом послідовної (щомісячної) публікації виявлених архівістами цінних документів - «свідчень епохи» - крізь призму подій кожного місяця революції. Користувачі можуть ознайомитися 3 оцифрованими копіями архівних документів на вебсайті або у читальному залі ЦДАВО України з можливістю безкоштовного отримання електронних копій документів.

Серед опублікованих нормативно-правових актів міжнародного i національного значення, актуальних для тематики дослідження, варто виокремити протокол засідання Малої Ради УЦР у м. Житомирі, датований 1 лютого 1918 р., про ратифікацію Брестського мирного договору з Німеччиною, Австро-Угорщиною, Туреччиною і Болгарією. Машинописний документ містить опис засідання Малої Ради та обговорення перспектив підписання договору. Зокрема, тодішній голова Ради Народних Міністрів В. Голубович поставив питання про його ратифікацію на порядок денний засідання, тоді як у документі зазначено, що М. Грушевський «нагадує про те, що Велика Рада надала урядові право підписати прелімінарний договір і що тепер урядом ставиться питання про поширення сього права на ратіфікацію мирного договору» ${ }^{13}$.

12 До 100-річчя Української революції (1917-1921) ЦДАВО України презентує проєкт «Українська революція: архівні хроніки» // Центральний державний архів вищих органів влади та управління України. URL: https://tsdavo. gov.ua/ukrayinska-revolyutsiya-arhivni-hroniky-2/ (дата звернення: 12.11.2021).

13 Про ратифікацію мирного договору України 3 Німеччиною, Австро-Угорщиною, Туреччиною і Болгарією та боротьбу з анархією в Україні - з протоколу засідання Малої Ради. 1 лютого 1918 р. // ЦДАВО України (Центральний державний архів вищих органів влади та управління України). Ф. 1064. Оп. 1. Спр. 10. Арк. 1. URL: http://tsdavo.gov.ua/novyny/30-sichnya2018-r/\#GmediaGallery_70-2131 (дата звернення: 15.11.2021). 
Протокол засідання у контексті ратифікації Брестського договору засвідчив одностайність прийняття рішення Малої Ради про передання повноваження урядові УНР для вирішення цього питання. Також оприлюднений документ містить важливу джерельну інформацію про плани військової допомоги з боку Німеччини у боротьбі з більшовиками ${ }^{14}$. Незважаючи на відсутність згадок про полонених або їхню репатріацію, відомо те, що ратифікація Брестського мирного договору уможливила проведення першої «хвилі» повномасштабної репатріації полонених із теренів Німеччини.

Не менш важливим нормативно-правовим актом у контексті мирних переговорів є доповідь генерального секретаря міжнаціональних справ УНР про перебіг мирних перемовин у Бресті від 11 січня 1918 р. Текст документа надрукований машинописом т. зв. «громадянським шрифтом», що побутував за часів Російської імперії. У доповіді йдеться про напружений хід переговорів між тодішнім генеральним секретарем міжнаціональних справ УНР О. Шульгиним та російськими представниками Ради солдатських депутатів ${ }^{15}$. Джерельний потенціал документа полягає у репрезентації підготовчого етапу для підписання визначального міжнародно-правового акта, що у подальшому вплинув на звільнення десятків тисяч полонених українців.

Важливе значення у контексті репатріації полонених українців відігравали постанови Ради Народних Міністрів УНР. На виставці ЦДАВО України «Українська революція: архівні хроніки» були представлені цифрові копії архівних документів, що характеризували діяльність Українського Червоного Хреста та військово-санітарних місій УНР. Так, увагу дослідників привертає постанова про асигнування 3 державних коштів 25 млн карбованців Головній управі Українського Червоного Хреста 3 переданням суми іiі уповноваженому представникові у Німеччині д-ру I. Холодному, що була підписана в. о. голови Ради Народних Міністрів А. Лівицьким 27 квітня 1920 р та затверджена Головою Директорії УНР С. Петлюрою ${ }^{16}$. Цей документ свідчить про надання урядом фінансової підтримки діяльності допомогових організацій за кордоном, попри надзвичайно складну ситуацію, в якій опинилася у той час Директорія УНР.

14 Там само.

15 Доповідь генерального секретаря міжнародних справ про хід мирних переговорів у Бресті. 11 січня 1918 р. // ЦДАВО України. Ф. 4592. Оп. 1. Спр. 6. Арк. 3. URL: http://tsdavo.gov.ua/novyny/2-sichnya-2018r/\#GmediaGallery_59-1528 (дата звернення: 4.11.2021).

16 Постанова Ради Народних Міністрів УНР про асигнування коштів Головній Управі Українського Червоного Хреста. 27 квітня 1920 р. // ЦДАВО України. Ф. 1065. Оп. 2. Спр. 76. Арк. 1. URL: http://tsdavo.gov.ua/novyny/1kvitnya-2020-r/\#GmediaGallery_201-6208 (дата звернення: 5.11.2021). 
Суттєву джерельну цінність має постанова Ради Народних Міністрів УНР про надання 300 тис. німецьких марок Військово-санітарній місії у справах полонених у Німеччині, призначених для проведення культурно-просвітницької і гуманітарної роботи у таборах. Цей документ, затверджений головою Директорії УНР С. Петлюрою, розкриває важливі аспекти державної підтримки українців у Німеччини. Зокрема, згадуються основні статті видатків, для покриття яких мають бути використані асигновані Військово-санітарній місії кошти: 1) платня іiі членам і співробітникам, оренда приміщень, відрядження, канцелярські витрати; 2) видання часопису і книжок для полонених, організація бібліотек, шкіл, театрів; 3) придбання додаткових харчів, білизни i забезпечення надання «лікарсько-санітарної допомоги» таборянам; 4) протези для інвалідів; 5) юридична допомога для полонених українців; 6) витрати на організацію репатріації.

У відповідь на асигнування коштів Військово-санітарна місія у Нiмеччині мусила надати звіт-кошторис Голові Української місії допомоги полоненим отаману А. Окопенку і військовому міністру Уряду УНР В. Сальському. Також прикметним $є$ те, що полонені характеризуються в джерелі як «полонені громадяни У.Н.Р.» ${ }^{17}$. Отже, цей документ має значну джерельну цінність, бо дозволяе встановити основні вектори діяльності військово-санітарних місій за кордоном, а також окреслити потреби українських таборових громад після Першої світової війни.

Важливою для вивчення проблеми репатріації полонених українців є затверджена 11 серпня 1920 р. головою Директорії УНР С. Петлюрою ухвала про розпуск військово-санітарних місій у Центральній і Південній Свропі - ключових інституцій, які займалися організацією евакуації полонених українців додому. Станом на кінець літа 1920 р. український уряд зіштовхнувся зі значними військово-політичними і фінансовими труднощами, тому забезпечення діяльності військово-санітарних місій було дуже проблематичним.

Аналіз змісту документа дає можливість отримати інформацію про: 1) процес ліквідації військово-санітарних місій у справах полонених, а також їхніх філій; 2) передання опіки над полоненими й інтернованими українцями за кордоном з юрисдикції Військового міністерства до Міністерства закордонних справ УНР; 3) створення спеціальної комісії з представників міністерств кількох відомств УНР задля здійснення контролю за процесом розформування місій; 4) передання майна і фі-

17 Про виділення коштів Військово-санітарній місії у справах полонених у Німеччині на видання часописів, улаштування театральних вистав у таборах, придбання протезів для поранених тощо. 3 Постанови Ради Міністрів УНР. 6 лютого 1920 р. // ЦДАВО України. Ф. 1429. Оп. 2. Спр. 6. Арк. 32. URL: http://tsdavo.gov.ua/novyny/05-lyutogo-2020-r/\#GmediaGallery_173-5880 (дата звернення: 17.11.2021). 
нансових ресурсів військово-санітарних місій на баланс Міністерства закордонних справ, тоді як їхній персонал виводився «поза штат» із забезпеченням їм платні за «заштатню допомогу» в австрійській валюті; 5) погашення боргів військово-санітарних місій та витрат, пов'язаних з їхньою ліквідацією, Міністерством закордонних справ на суму 1 млн 500 тис. австрійських корон ${ }^{18}$.

Підсумовуючи, зазначимо, що постанови Ради Народних Міністрів УНР мають важливе значення для аналізу перебігу процесу репатріації полонених українців. Завдяки даним з архівних документів дослідники можуть простежити динаміку та основні аспекти підтримки допомогових організацій українськими урядовими структурами, заглибитися в історичний контекст епохи та визначити головні перешкоди на шляху евакуації полонених українців із теренів країн Центральної і Південної Європи.

Варто наголосити на важливості аналізу інформаційного потенціалу офіційного листування між урядовцями державних структур за часів Центральної Ради, Української Держави і Директорії УНР. Цінним документом, опублікованим у рамках згадуваної електронної виставки ЦДАВО України, є лист «ревізора військових місій» за кордоном О. Жуковського до Головного Отамана С. Петлюри від 17 грудня 1919 р. Лист був написаний у формі звіту із зазначенням даних про кількість полонених у таборах станом на кінець 1919 р. (зокрема, згадуються 50 тис. «наддніпрянців» у Німеччині).

Розділ «Положення наших військовополонених за кордоном» містить цінну джерельну інформацію про українців у Німеччині, a саме: 1) переважна більшість полонених на той момент концентрувалася у Німеччині, оскільки в Австрії, Угорщині і Чехії залишилися лише одиниці, які знайшли роботу або одружилися; 2) тяжкі умови життя полонених та доцільність якнайшвидшого їхнього повернення на Батьківщину, особливо через зневіреність і духовне розчарування; 3) різноманітні перешкоди з боку німецького уряду, який ішов назустріч генералу А. Денікіну (зокрема, обумовлювалася можливість відпускати лише тих полонених, які були вихідцями 3 території, що іiі займали війська Директорії, тоді як решта мала відправлятися до Денікіна); 4) прагнення денікінців отримати контроль над фінансовими авуарами УНР у Німеччині. Також у листі ревізора йдеться про стан

18 Постанова Ради Народних Міністрів УНР про ліквідацію Військово-санітарних місій у справах полонених у Центральній і Південній Свропі та передачу справи допомоги полоненим українцям із Міністерства військових справ до Міністерства закордонних справ УНР. 3 Резолюцією Голови Директорії УНР С. Петлюри. 11 серпня 1920 р. // ЦДАВО України. Ф. 1065. Oп. 2. Спр. 139. Арк. 1. URL: http://tsdavo.gov.ua/novyny/3-serpnya-2020r/\#GmediaGallery_215-7600 (дата звернення: 19.11.2021). 
полонених-галичан в Італії ${ }^{19}$. Отже, цей документ містить важливу інформацію щодо становища полонених українців у 1919 р. у Німеччині, Італії, Австрії, Угорщині і Чехословаччині, певні статистичні дані, а також оціночні судження одного з високопосадовців Директорії УНР.

До числа інформативно насичених документів, опублікованих на сайті ЦДАВО України, належить і рапорт члена української дипломатичної місії у Польщі генерала-поручника В. Зелінського міністру військових справ УНР В. Сальському від 2 травня 1920 р. У цьому документі представлені плани щодо евакуації полонених українців із Нiмеччини; зокрема, обговорювалася можливість їхньої репатріації через Польщу безпосередньо до Бердичева, де вони мали увійти до складу Армії УНР ${ }^{20}$. Це джерело цінне для дослідження процесу звільнення полонених українців тим, що воно розкриває окремі аспекти планування евакуації дипломатичними і урядовими установами УНР.

Цінні джерельні свідчення про етапи репатріації містять колективні звернення полонених, а також документи, в яких відбилися настрої таборового загалу українців щодо певних дій з боку владних структур і вищих військових чинів на місцях. Неоціненно важливим у цьому контексті $€$ звернення генеральної старшини «Української громади» табору полонених українців у Зальцведелі, адресоване генералу В. Зелінському. Машинописний документ датований 18 лютого 1918 р. та засвідчений підписами голови М. Вовчика і секретаря М. Трезвінського. У зверненні висловлюється невдоволення призначенням на посади у таборах офіцерів «з гори», тоді як «Українська громада» виступала за «виборні підстави», наголошуючи, що «устрій у наших організаціях самий демократичний». Тому, громада табору Зальцведель зверталася 3 пропозицією узгодження призначень у подальшому, а також пропонувала використовувати в цій ролі офіцерів-українців, які постійно перебували серед таборян, адже «солдати довіряють ім цілковито» ${ }^{21}$.

19 Лист Ревізора Військових Місій за кордоном О. Жуковського Головному Отаману військ УНР С. Петлюрі про положення військовополонених за кордоном та їх кількість. 17 грудня 1919 р. // ЦДАВО України. Ф. 1065. Оп. 1. Спр. 32a. Арк. 22. URL: http://tsdavo.gov.ua/novyny/5-grudnya-2019r/\#GmediaGallery_146-5232 (дата звернення: 00.00.2021).

20 Рапорт голови секції з військових справ при українській дипломатичній місії в Речі Посполитій польській В. Зелінського міністру військових справ УНР про переведення запасної бригади під командуванням І. Феденяка-Білинського з Бреста до Бердичева тощо. 2 травня 1920 р. // ЦДАВО України. Ф. 1078. Оп. 2. Спр. 110. Арк. 58. URL: http://tsdavo.gov.ua/novyny/29-kvitnya2020-r/\#GmediaGallery_203-6770 (дата звернення: 20.11.2021).

21 Лист генеральної старшини «Української громади» в таборі полонених українців у Зальцведелі генералу [В.] Зелінському про узгодження призначень. 15 лютого 1918 р. // ЦДАВО України. Ф. 4055. Оп. 1. Спр. 5. Арк. 1. URL: http://tsdavo.gov.ua/novyny/30-sichnya-2018-r/\#GmediaGallery_70-2087 (дата звернення: 14.11.2021). 
Це джерело дозволяє докладніше ознайомитися з позицією полонених щодо організаційних процесів проведення повномасштабного звільнення та формування синьожупанних дивізій.

Проєкт телеграми громади полонених українців табору Йозефштадт, написаний каліграфічним почерком, дозволяє дослідникам простежити настрої і реакцію полонених на події на українських теренах. Документ, датований вереснем 1917 р., свідчить про обурення щодо нападу на «козаків Богданівців» із висловленням пропозиції вшанування «оборонців нашого Рідного Краю, що полягли від рук темних сил» ${ }^{22}$. У контексті нашого дослідження згадана телеграма цінна: 1) підтвердженням факту звернення полонених до Української Центральної Ради і прагненням таборян бути почутими владними структурами України; 2) наочним свідченням виявлення полоненими своїх патріотичних почуттів, а також їхнім співпереживанням за долю Батьківщини.

Посвідчення діячів, пов'язаних із репатріацією полонених українців із теренів Німеччини, також $є$ цінними джерелами для цього дослідження. Окремо варто відзначити посвідчення В. Сімовича як члена Просвітнього відділу в таборі Раштатт (Німеччина), датоване 23 вересня 1917 р. Документ засвідчує тісну співпрацю українських культурно-просвітніх діячів Союзу Визволення України з німецькою військовою владою і комендатурами таборів. На посвідченні присутня фотографія В. Сімовича, а також печатки німецької комендатури табору Раштатт із державною символікою і надписом «Russen-Lager Rastatt». Документ написаний німецькою мовою і містить інформацію про В. Сімовича як громадянина Австро-Угорщини й члена Просвітнього відділу табору Раштатт, чий паспорт був надісланий до Військового міністерства Німеччини з метою продовження його дії 23 . Прикметно, що в документі використовується термін «Russen Lager Rastatt» («російський табір Раштатт»), однак станом на 1917 р. він уже довший час був українським. Можна припустити, що таборова комендатура Раштатта не квапилася з виготовленням нової печатки, хоча вже на початку 1918 р. вона послуговувалася печаткою з надписом «Ukrainisches Lager Rastatt».

Свідчення про важливі аудіовізуальні документи з проблематики полону можна віднайти в оголошеннях про покази фільмів. «Об'ява»

22 Проєкт телеграми громади полонених офіцерів українців табору в Йозефові УЦР про глибоке обурення з приводу злочинного нападу на Богданівців. 12 вересня 1917 р. // ЦДАВО України. Ф. 3533. Оп. 1. Спр. 1. Арк. 4. URL: https://tsdavo.gov.ua/gmedia/25-3533-1-1-4-jpg/ (дата звернення: 20.11.2021).

23 Посвідчення В. Сімовича - члена Культурного комітету в таборі м. Раштатт, Німеччина. 23 вересня 1917 р. // ЦДАВО України. Ф. 4446. Оп. 1. Спр. 1. Арк. 2. URL: https://tsdavo.gov.ua/gmedia/15-4446-1-1-2-jpg/ (дата звернення: 19.11.2021). 
за 19-21 червня 1918 р. містить інформацію про вечірні сеанси 3 показом декількох кінострічок, у т. ч. історичних хронік. У контексті дослідження репатріації полонених варто виокремити такі назви картин, як «Берестейська мирна конференція» і «Парад першої дивізії полонених» ${ }^{24}$, що свідчить про факт висвітлення подій для тогочасних українських глядачів не лише міжнародного або національного, а й таборового значення.

Отже, онлайн-проєкт ЦДАВО України «Українська революція: архівні хроніки» презентує унікальну добірку електронних архівних ресурсів - оцифрованих документів доби 1917-1921 рр., що дозволяють заглибитися у контекст епохи лише за допомогою мережі Інтернет i віднайти релевантні джерела для різноманітних досліджень. Більшість оцифрованих документів має високу розподільну якість, однак із низкою опублікованих копій неможливо ознайомитися через розмитість та нечіткість зображення (зокрема, йдеться про наказ військового міністра УНР, в якому оголошується подяка отаману «Синьожупанної» дивізії В. Зелінському ${ }^{25}$, а також щоденник старшого значкового штабу I Української дивізії про процес перевезення ії особового складу в Україну $\left.{ }^{26}\right)$.

Окрім архівних ресурсів ЦДАВО України, цінне джерельне значення для дослідників окресленої проблеми мають електронні публікації ЦДАЗУ. Зокрема, 2 підготовлені архівом у 2010-2013 рр. виставки електронних документів були дотичні до теми репатріації полонених українців із теренів Німеччини, а саме: «3 життя української еміграції. Табори для інтернованих українців у країнах Свропи (1919-1924)» та «Театральне життя українців за кордоном». Попри те, що фонди ЦДАВО України мають найбільшу джерельну цінність для нашого дослідження, колекції ЦДАЗУ дозволяють розкрити деякі додаткові аспекти життя і побуту полонених українців після Першої світової війни.

24 Об'ява про показ кінематографічних картин «Похорони жертв більшовиків у Києві», «Похорони юнаків, забитих під Крутами», «Берестейська мирна конференція», «Парад Першої дивізії полонених», «Шевченківське свято», «Катастрофа на Звіринці» та виступ артистів Національного театру. 19-21 червня 1918 р. // ЦДАВО України. Ф. 2201. Оп. 1. Спр. 326. Арк. 26. URL: http://tsdavo.gov.ua/novyny/1-chervnya-2018-r/\#GmediaGallery_116-4552 (дата звернення: 20.11.2021).

25 Наказ військового міністра УНР про подяку отаману І-ої української дивізії полонених [В.] Зелінському за організацію військових частин. 29 березня 1918 р. // ЦДАВО України. Ф. 1074. Оп. 2. Спр. 30. Арк. 41a. URL: https://tsdavo.gov.ua/gmedia/12-1074-2-30-41_-jpg/ (дата звернення: 22.11.2021).

26 Про повернення до України - 3 щоденника старшого значкового штабу І-ої української дивізії. [Березень] 1918 р. // ЦДАВО України. Ф. 4055. Оп. 1. Спр. 5. Арк. 10. URL: https://tsdavo.gov.ua/gmedia/2-4055-1-5-10-jpg/ (дата звернення: 16.11.2021). 
У першій згаданій виставці представлені різноманітні групи джерел із періоду інтернування українців на теренах Польщі, Чехословаччини й Румунії, зокрема у таборах Ланцут, Німецьке Яблонне, Йозефов, Орадя-Маре тощо. Виставка містить цілу низку цінних документів: оцифровані тижневики і вісники, фотографії інтернованих і таборів та навіть печатки комісій 3 перевірки військових звань ${ }^{27}$. Цей джерельний комплекс дозволяє провести компаративний аналіз з історичним контекстом інтернування на теренах Німеччини для виявлення спільних і відмінних рис полону в країнах Центрально-Східної Свропи.

Натомість ще одна згадана виставка ЦДАЗУ, матеріали якої відтворювали зусилля українців у царині організації театрально-драматичних подій за кордоном, дає дослідникам можливість розкрити зміст культурно-просвітницьких ініціатив, пов'язаних із національно-патріотичним вихованням таборян, істотну допомогу в чому надавали політичні і гуманітарні організації. Хронологічні рамки опублікованих в електронному форматі документів охоплюють 1915-1922 pp. Ці документи багатогранно представлені світлинами акторів і театральних сцен, посвідченнями, газетними шпальтами зі згадками вистав, афішами і віршованими п'єсами ${ }^{28}$.

Окремий пласт електронних ресурсів із теми репатріації полонених після Першої світової війни також представлений у репозиторіях низки зарубіжних архівів і бібліотек. Цінну джерельну інформацію 3 проблематики дослідження можна віднайти на порталах «Europeana», «Archives Portal Europe», вебсайтах Федерального архіву Німеччини (Bundesarchiv) і Британської бібліотеки (The British Library), а також у репозиторіях «Open Library», «Internet Archive» тощо. Зазначені ресурси переважно містять оцифровані документи (фотографії, кінохроніки, посвідчення, листи, щоденники, спогади).

Особливе значення у цій категорії посідає «Europeana» - репозиторій метаданих оцифрованої культурної спадщини європейських архівних і бібліотечних зібрань. На платформі репрезентовано документи 3 близько 3 тис. 200 європейських архівів, бібліотек, аудіовізуальних інституцій і музеїв. Важливим є те, що всі оцифровані документи містять відповідні описи і посилання на вебсайти тих інституцій, де вони зберігаються ${ }^{29}$. Фактично «Europeana» діє як об'єднуюча платформа та

273 життя української еміграції. Табори для інтернованих українців у країнах Європи (1919-1924) // ЦДАЗУ (Центральний державний архів зарубіжної україніки). URL: https://tsdazu.archives.gov.ua/archives/118 (дата звернення: 29.10.2021).

28 Театральне життя українців за кордоном // ЦДАЗУ. URL: https://tsdazu. archives.gov.ua/archives/243 (дата звернення: 29.10.2021).

29 Petras V., Hill T., Stiller J., Gäde M. Europeana - a Search Engine for Digitised Cultural Heritage Material. Datenbank Spektrum. 2017. Vol. 17, № 4146. P. 41. 
інструмент пошуку за ключовими термінами і категоріями серед численних європейських колекцій.

Найбільш цінним електронним ресурсом із питань репатріації полонених українців у рамках цього репозиторію $є$ кінохроніка «Ukrainer in Wetzlar 1919» 3 колекції О. Барнака, що зберігається в Німецькому кіноінституті (Deutsches Filminstitut). Кадри цієї кінострічки відтворюють життя полонених українців у таборі Вецляр у 1918-1919 pр., фіксуючи для історії унікальні свідчення таборового повсякдення і звільнення українців із полону. У хроніці наявні сцени освячення українського прапора, урочистого проходу полонених українців в уніформах у супроводі українського таборового оркестру, а також кадри маршу вояків із табору до залізничного вокзалу. Окрім цього, аудіовізуальний ресурс містить сюжети з інших тогочасних кінокартин із фіксацією українського пам'ятника, встановленого 16 серпня 1919 р. ${ }^{30}$ Завдяки кінохроніці стає можливим встановити і візуалізувати зовнішній вигляд полонених й облаштування таборів, одяг таборян і однострої службовців німецької комендатури, склад військового оркестру в таборі, а також факт участі цивільних осіб (як німців, так і українців) у таборових подіях.

Варто також відзначити, що окремі документи і зображальні джерела, представлені на платформі «Europeana», надають цінний матеріал для вивчення процесу репатріації після Першої світової війни. Так, однією з яскравих ілюстрацій процесу звільнення полоненого є документи 3 колекції Дж. Бьорке - 3 картки від Секретаріату відділення поранених та осіб, які зникли безвісти, Британського Червоного Хреста ${ }^{31}$, на підставі яких ухвалювалося рішення репатріювати полоненого внаслідок його поранення. Особливої уваги заслуговує оформлення документів, для яких секретаріат виробив шаблон тексту з чіткими інструкціями медичного огляду при поверненні на Батьківщину, а також печатки 3 написами «Repatriated Prisoner of War» та «"D” Group POW Reception», що дозволяє ознайомитися 3 оформленням діловодства військового часу при звільненні полонених.

Для аналізу документів проміжного етапу репатріації полонених на шляху додому в нагоді стають ідентифікаційні картки, одним iз прикладів яких є документи капітана Н. Коллінса ${ }^{32}$, виготовлені в Нідерландах. Ідентифікаційні картки були призначені для рукописно-

30 Ukrainer in Wetzlar 1919 // Europeana. URL: https://www.europeana. eu/en/item/08604/5796DFC2F8FA46AFB30A643DF6618B6D (дата звернення: 19.10.2021).

31 The private James Burke collection (documents of the British Red Cross) // Europeana. URL: https://www.europeana.eu/en/item/2020601/https__1914_1918_ europeana_eu_contributions_3626 (дата звернення: 20.10.2021).

32 ID card, Holland. January 1919 // Europeana. URL: https://www.europeana. eu/en/item/2020601/https__1914_1918_europeana_eu_contributions_4025_ attachments_48257 (дата звернення: 15.10.2021). 
го заповнення з роздрукованими анкетними питаннями про підрозділ, найближчих родичів, професію до війни і в майбутньому, сімейний статус тощо. У правому куті документа вклеєно фото звільненого полоненого, основна інформація заповнена вручну чорними, а номер полку позначений червоними чорнилами.

Після повернення полонених додому вони зазвичай підлягали демобілізації. Так, «Сертифікат із демобілізації» рядового Р. Гріффітса, датований 11 квітня 1919 р., оформлений у вигляді анкети ${ }^{33}$, де переважно різні нерелевантні варіанти відповіді викреслювалися відповідальним за заповнення сертифікату. Це джерело демонструє включення Р. Гріффітса до резерву армії, що, ймовірно, було зумовлено його фізичним станом. Інформація про належність до полку, зарахування до резерву, наявність медалей і орденів тощо заповнювалися синім чорнилом та олівцем, тоді як сам документ має діловодний номер «Z.21».

Варто також виокремити такий документ, як «Спеціальна перепустка №1338» ${ }^{34}$ із печаткою «Humber Garrison, Hull», видана місіс Коуквелл та іiі доньці для можливості зустрічі у порту «Riverside Quay» звільнених полонених. Перепустка виконана в машинописному вигляді з підписом капітана Генерального штабу, номер перепустки й адресати запрошення вписані рукописно синіми чорнилами. На нашу думку, цей документ яскраво засвідчує той ступінь уваги, яка надавалася питанням опіки і допомоги репатрійованим особам.

Увагу дослідника привертає й лист короля Георга V до звільненого британського полоненого С. Райта 3 подякою репатрійованому солдату за службу, терпіння і сміливість, особливо у період перебування останнього у полоні. Прикметно, що лист монархом написаний і підписаний власноруч; на ньому зображений герб Великої Британії 3 надписом «Букінгемський палац» ${ }^{35}$. Подібний приклад кореспонденції $є$ неординарним свідченням комунікації державних діячів із солдатами з числа полонених.

Важливі діловодні документи і кореспонденція розміщені на вебресурсі Британської бібліотеки у розділі оцифрованих рукописів. У каталозі «MS 62469» аркуші f1r-f.218r присутня цінна джерельна інформація про репатріацію полонених із теренів Німеччини та можливостей використання для цього транспортних шляхів; процедури проведення

33 Demobilization papers of private Richard Griffiths. April 1919 // Europeana URL: https://www.europeana.eu/en/item/15601/689A93DC62F20464CEB70CF307 46F363СCF85ЕС9 (дата звернення: 20.10.2021).

34 Special pass issued to Mrs Cawkwell and daughter. 1919 // Europeana URL: https://www.europeana.eu/en/item/15601/B77CFA3E54309B5615E823DB0 10456B8A9BA81C7 (дата звернення: 21.10.2021).

35 Prisoner of War Letter // Europeana URL: https://www.europeana.eu/en/ item/2020601/https_1914_1918_europeana_eu_contributions_17236 (дата звернення: 29.10.2021). 
звільнення після Комп'єнського перемир'я; статистичних даних щодо кількості репатрійованих полонених; делегування відповідальності за репатріантів нейтральним державам, зокрема Голландії на проміжних пунктах репатріації; переговори союзників із питань транспортування полонених морським шляхом тощо. Колекції Британської бібліотеки також містять цінну інформацію про гуманітарну діяльність Червоного Хреста, фінансових можливостей цієї благодійної організації, дискусій навколо процедури евакуації і свідчень окремих полонених про бажання залишитися на теренах Німеччини. Джерельний комплекс ресурсу представлений телеграмами, рапортами, листами до владних структур, організацій і редакцій періодичних видань ${ }^{36}$.

Крім цього, варто виокремити кінохроніку підписання Брестського мирного договору 9 лютого 1918 р., опубліковану на сайті Федерального архіву Німеччини. Кінострічка зображує зібрання ключових дипломатів Центральних держав під час підписання миру з українською делегацією. Кадри хроніки фіксують процес підписання договору, скріплення його печатками, дають можливість побачити основних діючих осіб, пов'язаних із цією історичною подією. Так, представниками української делегації були М. Любинський, М. Левитський, О. Севрюк i C. Остапенко - у хроніці їх охарактеризували як «Die Ukrainische Volksdeputation». Прикметно те, що кінохроніка фіксувала не лише процес підписання договору, а й святковий бенкет із нагоди його ратифікації. Також варто відзначити, що останні кадри хроніки демонструють оригінал договору 3 підписами представників делегацій ${ }^{37}$.

Отже, українські і зарубіжні архіви проводять масштабну роботу 3 цифровізації документів, вдосконалюють інструменти репрезентації і пошуку документної інформації, наповнюють повнотекстові бази даних і репозиторії, реалізують електронні виставкові проєкти, тим самим розширюючи доступ дослідників до історико-культурної спадщини. Цифрові архівні ресурси перетворюються на важливе джерело наукових досліджень, дозволяючи залучити інструментарій новітніх технологій до творчої лабораторії істориків.

Тема репатріації полонених українців із теренів Німеччини після Першої світової війни не $є$ винятком. Оцифровані архівні документи 3 питань організації й проведення звільнення полонених, шляхів їхньої евакуації, репрезентовані на українських і зарубіжних вебресурсах, на-

36 Cave papers. Official documents relating to prisoners of war. November, December 1918. British Library: Digitalized Manuscripts. MS 62469, f1r - f.218r // British Library. URL: http://www.bl.uk/manuscripts/Viewer.aspx?ref=add_ ms_62469_f001r (дата звернення: 10.20.2021).

37 Der erste Friedensvertrag des Weltkrieges 1918 // Das Bundesarchiv. URL: https://www.filmothek.bundesarchiv.de/video/9381?topic=doc6ynfw8d8et4r 5 bjceqm\&start $=00 \% 3 \mathrm{~A} 00 \% 3 \mathrm{~A} 00.00 \&$ end $=00 \% 3 \mathrm{~A} 10 \% 3 \mathrm{~A} 09.17$ (дата звернення: 6.11.2021). 
лежать до категорії цінних джерел, що мають важливий інформаційний потенціал для вивчення цієї дослідницької проблеми.

Таким чином, зростання темпів і обсягів цифровізації архівних документів, що спостерігається останнім часом в Україні, створює більш сприятливі умови для доступу до інформації та розширює можливості дослідників у іiі пошуку і використанні. Крім того, перспективним напрямом подальших наукових студій є поглиблене вивчення цифрового контенту зарубіжних архівів і бібліотек із метою виявлення та залучення до наукового обігу цінних джерел з української історії.

\section{REFERENCES}

1. Biluschak, T. (2019). Pytannia dostupu do istoryko-kulturnoi spadschyny Ukrainy: elektronni arkhivy [The issue of access to the historical and cultural heritage of Ukraine: electronic archives]. Abstract of Papers '19: Informatsiia, komunikatsiia ta upravlinnia znanniamy u hlobalizovanomu sviti: zbirnyk materialiv Druhoi mizhnarodnoi naukovoi konferentsii (pp. 20-23). Kyiv. [in Ukrainian].

2. Boriak, H. V. (2002). Elektronni arkhivni publikatsii v Interneti: problemy reprezentatsii informatsijnykh resursiv [Electronic archival publications on the Internet: problems of information resources representation]. Arkhivy Ukrainy, 4-6, 141-169. [in Ukrainian].

3. Cave papers. Official documents relating to prisoners of war. November, December 1918. British Library: Digitalized Manuscripts. MS 62469, f1r - f.218r. Retrieved from http://www.bl.uk/manuscripts/Viewer.aspx?ref=add_ms_62469_ f001r [in English].

4. Cook, T. (2007). Electronic Records, Paper Minds: The Revolution in Information Management and Archives in the Post-Custodial and Post-Modernist Era. Archives \& Social Studies: A Journal of Interdisciplinary Research, 1, 399443. [in English].

5. Der erste Friedensvertrag des Weltkrieges 1918. Das Bundesarchiv [The first peace treaty of the World War in 1918. The German Federal Archives]. Retrieved from https://www.filmothek.bundesarchiv.de/video/9381?topic=doc6ynfw8d8et4r5 bjceqm\&start $=00 \% 3 \mathrm{~A} 00 \% 3 \mathrm{~A} 00.00 \&$ end $=00 \% 3 \mathrm{~A} 10 \% 3 \mathrm{~A} 09.17$ [in German].

6. Do 100-richchia Ukrainskoi revoliutsii (1917-1921) TsDAVO Ukrainy prezentuie proekt «Ukrainska revoliutsiia: arkhivni khroniky» [To the 100th anniversary of the Ukrainian Revolution (1917-1921): the Central State Archives of Supreme Bodies of Power and Government of Ukraine presents the project «Ukrainian Revolution: Archival Chronicles».]. Retrieved from https://tsdavo.gov. ua/ukrayinska-revolyutsiya-arhivni-hroniky-2/ [in Ukrainian].

7. Dubrovina, L. A. (1998). Osnovni polozhennia kontseptsii kompiuteryzatsii arkhivnoi spravy [The main aspects of the concept on computerization of archives]. Studii z arkhivnoi spravy ta dokumentoznavstva, 3, 6-17. [in Ukrainian].

8. Gold, M. K. (2012). Debates in the Digital Humanities. Minnesota. [in English].

9. Hedstrom, M. (1995). Electronic Archives: Integrity and Access in the Network Environment. The American Archivist, 58, 312-324. [in English]. 
10. Kalakura, Ya. \& Paliienko, M. (2021). Kontseptualizatsiia elektronnoho arkhivoznavstva $\mathrm{v}$ konteksti tsyfrovizatsii ukrainskoho suspilstva [The conceptualization of electronic archives in the context of digitalization of Ukrainian society]. Arkhivy Ukrainy, 3, 36-65. [in Ukrainian].

11. Kovtaniuk, Yu. (2011). Vytoky elektronnoho dokumentoznavstva yak naukovoho napriamu dokumentoznavstva [Origins of electronic records management as a scientific field of records management]. Arkhivy Ukrainy, 2-3, 14-36.

12. Kulikov, V. (2013). Digital History: stanovlennia, suchasnyi stan, perspektyvy [Digital history: the establishment, current state, prospects]. Spetsialni istorychni dystsypliny, 21, 27-44. [in Ukrainian].

13. Levchenko, L., Popova, L. \& Khromov, A. (2021). Natsionalni arkhivni informatsiini resursy: pravovi zasady reformuvannia arkhivnoi spravy [National archival information resources: legal framework of archival affairs reform]. Visnyk Luhanskoho derzhavnoho universytetu vnutrishnikh sprav imeni E. O. Didorenka, 93(1), 249-263. [in Ukrainian].

14. Papakin, H. (2010). Suchasna ukrainska internet-arkheohrafiia: osnovni formy ta dzherela elektronnykh publikatsii [Modern Ukrainian Internet archeography: main forms and sources of electronic publications]. Ukrainskyi istorychnyi zhurnal, 5, 153-166. [in Ukrainian].

15. Papakin, H. (2012). Elektronna arkheohrafiia: novitnii napriam staroi nauky, ii skladovi ta stan doslidzhennia [Electronic archeography: the newest direction of the old science, its components, and the research status]. Bibliotekoznavstvo. Dokumentoznavstvo. Informolohiia, 2, 25-33. [in Ukrainian].

16. Petras V., Hill T., Stiller J., Gäde M. (2017). Europeana - a Search Engine for Digitised Cultural Heritage Material. Datenbank Spektrum, 17, 41-46.

17. Prelinger, R. (2007). Archives and Access in the 21 st Century. Cinema Journal, 46(3), 114-118. [in English].

18. Stratehiia rozvytku arkhivnoi spravy na period do 2025 roku (proiekt) (2020) [Strategy for the development of archives for the period until 2025 (project)]. Arkhivy Ukrainy, 4, 15-16. [in Ukrainian].

19. Teatralne zhyttia ukraintsiv za kordonom. Vystavka Tsentralnoho derzhavnoho arkhivu zarubizhnoi ukrainiky [Theatrical life of Ukrainians abroad. Exhibition of the Central State Archives of Foreign Archival Ucrainica]. Retrieved from https://tsdazu.archives.gov.ua/archives/243 [in Ukrainian].

20. Warwick, C., Terras, M. \& Nyhan, J. (2021). Digital Humanities in Practice. Facet Publishing. [in English].

21. Yemelianova, T. (2016). Audiovizualni kolektsii: otsyfruvannia ta dostup (na prykladi Tsentralnoho derzhavnoho kinofotofonoarkhivu Ukrainy imeni H. S. Pshenychnoho) [Audiovisual collections: digitization and access (on the example of the H. Pshenychnyi Central State CinePhotoPhono Archives of Ukraine)]. Visnyk Kyivskoho natsionalnoho universytetu imeni Tarasa Shevchenka. Istoriia, 3, 33-35. [in Ukrainian].

22. Z zhyttia ukrainskoi emihratsii. Tabory dlia internovanykh ukraintsiv u krainakh Yevropy (1919-1924). Vystavka Tsentralnoho derzhavnoho arkhivu zarubizhnoi ukrainiky [From the life of Ukrainian emigration. Camps for interned Ukrainians in European countries (1919-1924). Exhibition of the Central State Archives of Foreign Archival Ucrainica]. Retrieved from https://tsdazu.archives. gov.ua/archives/118 [in Ukrainian]. 
Milana Sribniak

Master of History,

Ph.D. student,

Institute of World History

of the National Academy of Sciences of Ukraine

ORCID: https://orcid.org/0000-0003-1353-3001

\title{
DIGITAL ARCHIVAL RESOURCES AS A SOURCE FOR STUDYING THE PROCESS OF UKRAINIAN PRISONERS' OR WAR REPATRIATION AFTER WWI
}

\begin{abstract}
The aim of this article is to determine and systematize digital archival resources on the topic of Ukrainian prisoners' of war (POWs) repatriation after the First World War; to analyze the content of Ukrainian and foreign databases as well as digitized archival collections where scholars can find documents on this research problem. The methodology of the research includes the principles of historicism, comprehensiveness, continuity; the article uses methods of comparative analysis and synthesis, systemic and interdisciplinary approaches. The archival resources study was maintained from the perspective of digital humanities approaches. Scientific novelty. The author defined the body of digitized documents at Ukrainian and foreign archives that highlight the process of POWs' repatriation after WWI. Particular attention was paid to expanding access for scientists to digitized archival resources. The importance of digital humanities and its impact on modern research practices was highlighted. The author observed common trends in the representation of fonds and collections on websites of Ukrainian and foreign archives, libraries, and other institutions. Conclusions and future research prospects. It was determined that the issue of prisoners' of war repatriation after the First World War, including Ukrainian POWs, has gradually become more represented in digital space. The author defined the role and place of digital archival resources in researching the process of repatriation; systematized the main source groups that are highlighted in Ukrainian and foreign archival databases and exhibition projects (i. e., the Central State Archives of Supreme Bodies of Power and Government of Ukraine, Central State Archives of Foreign Archival Ucrainica, the German Federal Archives, Europeana web portal etc.). The article emphasizes that deep study of Ukrainian and foreign archives' and libraries' digital content is a prospective scientific focus area in order to uncover valuable sources of Ukrainian history.
\end{abstract}

Key words: digital archival resources; historical sources; Ukrainian prisoners of war; repatriation; First World War (WWI); information potential; digital humanities. 